\title{
Functional Cosmetic Effects of Dendropanax, Sea Salt, and Other Extracts to Alleviate Hair Loss Symptoms
}

Yun-Hee Choi, Yeon-Je Cho, Byung-Loc Kim, Min-Hee Han, Hak-Sung Lee, Yong-Gi Jeong*

Center of Natural Resources Research, Jeonnam Bioindustry Foundation, Jangheung-gun, Jeollanam-do, Korea

*Corresponding author: Yong-Gi Jeong, Center of Natural Resources Research, Jeonnam Bioindustry Foundation, 288 Woodland-gil, Anyang-myeon, Jangheunggun, Jeollanam-do 59338, Korea

Tel.: +82618602630

Fax: +8261864 7105

Email: go6115@nate.com

Received October 28, 2020

Revised January 18, 2021

Accepted January 20, 2021

Published March 30, 2021

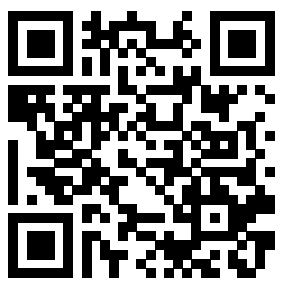

\begin{abstract}
Purpose: Here, we evaluated the safety and effectiveness of Jeonnam's unique resources, such as Dendropanax, sea salt, spinach, and kelp, to develop functional cosmetics that may alleviate hair loss. Methods: We performed safety tests with these resources, testing for heavy metals and cytotoxicity, and we evaluated their effectiveness as anti-microbial, cell proliferation, and anti-inflammation products. Results: The heavy metals concentration was lower than or in trace levels, as recommended by the Ministry of Food and Drug Safety's standard of extracts such as Dendropanax, sea salt, etc. We confirmed cytotoxicity to be safe. In each extract, the concentrations of Dendropanax, sea salt, spinach, and kelp were $0.01 \mathrm{mg} / \mathrm{mL}$, $5 \mathrm{mg} / \mathrm{mL}, 0.5 \mathrm{mg} / \mathrm{mL}, 0.5 \mathrm{mg} / \mathrm{mL}$, respectively. Only the Dendropanax extract had microbial effect, with the distilled water extract reaching the highest effect. The cell proliferation increased to $0.5 \mathrm{mg} / \mathrm{mL}, 5 \mathrm{mg} / \mathrm{mL}$, and $2 \mathrm{mg} / \mathrm{mL}$ for Dendropanax, spinach, and kelp with distilled water extract, the anti-inflammation effect increased. Conclusion: We found that Dendropanax, sea salt, spinach, and kelp were safe and effective as functional cosmetic materials to alleviate hair loss symptoms through optimal standardization. We suggest further research to evaluate these cosmetics' functional effects.
\end{abstract}

Keywords: Dendropanax, Sea salt, Safety, Functional cosmetics, Hair loss symptoms

\section{Introduction}

현대인은 각종 산업공해와 스트레스, 인스턴트 식품의 과잉섭취, 미네랄 부족 및 화학제품의 남용 등으로 면역력이 약화되고, 모발손 상, 두피 트러블 및 탈모 등에 항시 노출되어 있다. 이러한 다양한 요 인들로 인하여 현대인의 탈모 인구는 지속적으로 증가하고 있으며, 최근에는 증상이 남성에만 국한된 것이 아니라 여성과 낮은 연령층 에게 까지도 확대되고 있어 탈모에 대한 문제는 날로 심각해져 가고 있다(Kim et al., 2019a).

이에 다양한 외용제가 시중에 시판되어 있고, 그 중에서도 미국 $\mathrm{FDA}$ 의 승인을 받은 미녹시딜(minoxidil)은 모세혈관 확장 기능 때 문에 두피에 바름으로써 탈모를 방지하지만, 매일 2회씩 지속적으 로 발라야 하고, 3-4시간 약제가 두피에 머물러야만 효과가 나타날 수 있다. 특히 사용시 어지럼증과 두피의 건조함, 그리고 가려움증, 피부자극 및 홍반 등의 부작용도 수반될 수 있다(Pinnell \& Murad, 1987; Rossi et al., 2012).
한편 FDA의 승인을 받은 내복약, 피나스테리드(finasteride)는 남 성 호르몬인 $5 \alpha$-dihydrotestosterone (DHT)의 생성을 억제하여 탈 모 유발을 방지하며, 약 6 개월-1년 정도 복용해야만 발모 또는 탈모 억제 효과가 나타나지만, 복용을 중단하면 2 개월 안에 원상태로 돌 려놓는 문제점이 있다. 또한 성욕감퇴, 발기부전 등의 성기능 저하와 여성의 경우 기형아 출산 위험이 있기 때문에 복용을 제한하고 있는 실정이다(Kim \& Park, 2020).

이와 같은 부작용을 없애기 위해 최근 인체에 무해한 천연 식물 추 출물로부터 두피에 바르거나 복용함으로써 발모를 촉진시키려는 시 도가 이루어지고 있다. 특히 발모촉진이나 탈모방지에 효과가 뛰어 난 천연물에 대한 연구가 추진되고 있으며, 이에 황칠나무 열수 추 출물에서 분리한 베타-시토스테롤( $\beta$-sitosterol)이 다양한 피부개 선효과와 탈모방지에 효과가 있는 것으로 보고되었다(Lee et al., 2015a). 또한, 국내산 천일염은 외국산에 비해 높은 미네랄을 함유 하고 있어 피부의 수분보호, 피부미용 및 두피케어 등에 도움을 줄 수 있는 것으로 알려져 있으며, 면역력 강화, 천식 완화, 심혈관 보 
호, 근육통 완화, 소화 촉진 및 우울증 해소 등 여러 방면에 효능이 입증되고 있다(Kim et al., 2015). 또한 국내산 시금치와 다시마는 항산화제가 풍부하고, 요오드 및 미네랄 성분이 함유되어 두피 건강 에 도움을 줄 수 있는 것으로 알려져 있다(Lee et al., 2015b; Jung et al., 2019).

따라서 본 연구는 전남 특산자원인 황칠, 천일염, 시금치 및 다시 마 등으로부터 탈모증상 완화에 도움을 줄 수 있는 기능성 화장품 개 발을 위해 소재의 안전성 및 유효성을 입증하고자 수행되었다.

\section{Materials \& Methods}

\section{1. 시험 재료}

본 연구에 사용한 황칠나무(Dendropanax)는 전남 장흥산으로 구 입하여 주로 잎과 잔 가지를 세척하고, 실내에서 자연 건조하였다. 천일염(sea salt)은 신안 비금도산으로써 탈수하고, 가는 입자로 가 공 및 멸균하였다. 또한 시금치(spinach)도 신안 비금도산으로 구 입하여 세척 후 $50^{\circ} \mathrm{C}, 12 \mathrm{~h}$ 열풍 건조하였고, 다시마(kelp)는 완도 산 건다시마를 구입하여 염분을 제거하고 세척 후 $50^{\circ} \mathrm{C}, 6 \mathrm{~h}$ 열풍 건조하였다. 각 시험 재료는 열수(distilled water), $30 \%$ 주정(30\% ethanol) 및 $60 \%$ 주정 $(60 \%$ ethanol)으로 $8 \mathrm{~h}$ 동일하게 가온 추출하 였고, 추출 후 $-70^{\circ} \mathrm{C}, 24 \mathrm{~h}$ 초저온냉동 및 $-45^{\circ} \mathrm{C}-50^{\circ} \mathrm{C}, 72 \mathrm{~h}$ 동결 건조하였다. 이에 최종적으로 획득한 열수 추출물, $30 \%$ 주정 추출물 및 $60 \%$ 주정 추출물을 대상으로 본 연구에 사용하였다.

\section{2. 안전성 시험}

I. 중금속

중금속은 유통화장품 안전관리 시험방법을 적용하여 유도결합 플라즈마 분광분석기 (Optima 7000DV; PerkinElmer, USA)로 시 험하였다(Hu et al., 2005; Jung et al., 2007; Jung et al., 2011; Kim et al., 2014; Kim et al., 2019b). 납(Pb), 비소(As) 및 카드뮴 $(\mathrm{Cd})$ 은 각 중금속 표준원액 $(1,000 \mathrm{mg} / \mathrm{L})$ 에 $0.5 \mathrm{~mol} / \mathrm{L}$ 질산으로 희 석하고, 공시액으로 보정한 후 유도결합플라즈마 분광분석기로 흡 광도를 측정하였다. 이때 납, 비소 표준용액의 농도는 $0.1,0.5$ 및
$1 \mathrm{mg} / \mathrm{L}$ 이었고, 카드뮴 표준용액의 농도는 $0.01,0.05$ 및 $0.1 \mathrm{mg} /$ L이었다. 또한 수은 $(\mathrm{Ag})$ 은 수은전용 분석기(Hydra II ; Teledyne Leeman Labs, USA)를 이용하여 시료 $0.1 \mathrm{~g}$ 을 강열 방냉한 보트에 넣고, $300^{\circ} \mathrm{C}, 20 \mathrm{~s}$ 건조 후 $600^{\circ} \mathrm{C}, 1 \mathrm{~min}$ 열분해하여 분석하였다.

\section{II. 세포 독성}

세포 독성을 위한 모유두세포(human follicle dermal papilla cell, HFDPC; Genophile, Korea)는 90\% dulbecco's modified eagle's medium (DMEM; Gibco, USA), 10\% fetal bovine serum (FBS; Millipore, USA) 및 $1 \%$ penicillin and streptomycin antibiotics (P/ $\mathrm{S}$; Gibco, USA)를 첨가한 배지에 $37^{\circ} \mathrm{C}, 5 \% \mathrm{CO}_{2}$ 조건으로 incubator 에서 배양하였다. 배양된 세포는 96 well plate에 well당 $1 \times 10^{6}$ cells 로 $100 \mu \mathrm{L}$ 를 분주하여 $37^{\circ} \mathrm{C}, 5 \% \mathrm{CO}_{2}, 12 \mathrm{~h}$ incubator에서 안정화 하였고, $12 \mathrm{~h}$ 후 serum free배지로 희석한 추출물을 농도별로 처리 하였다. 황칠 추출물은 $0.01,0.05$ 및 $0.1 \mathrm{mg} / \mathrm{mL}$ 로 처리하였고, 천 일염, 시금치 및 다시마 추출물은 $0.1,0.5,1,5 \mathrm{mg} / \mathrm{mL}$ 로 처리한 후 incubator에 $24 \mathrm{~h}$ 배양하였다. EZ-Cytox (DoGenBio, Korea)를 well 당 $10 \mu \mathrm{L}$ loading하고 $4 \mathrm{~h}$ 안정화 후, $\mathrm{OD} 450 \mathrm{~nm}$ 에서 흡광도 를 측정하였다. 이때 사용한 대조군으로는 serum free배지로 희석된 물, $30 \%$ 주정 및 $60 \%$ 주정을 사용하였다.

\section{3. 유효성 시험}

\section{I. 항균 활성}

항균 활성은 그람 음성균인 녹농균(Pseudomonas aeruginosa, P. aeruginosa; KCTC 2004)과 그람 양성균인 황색포도상구균 (Staphylococcus aureus, S. aureus; KCTC 1927)을 대상으로 각 추출물에 대하여 paper disc (Advantec, Japan)법으로 시험하였다 (Table 1). 균주는 Luria-Bertani (BD Difco, USA) 배지를 사용하여 shaking incubator에서 $120 \mathrm{rpm}, 37^{\circ} \mathrm{C}, 12 \mathrm{~h}$ 배양하였다(Mostafa et al., 2018). 배양한 균주는 $1 \times 10^{6}$ cells $/ \mathrm{mL}$ 로 희석 후 배양액 $100 \mu \mathrm{L}$ 를 LB배지에 도말하였고, paper disc에 열수 추출물, $30 \%$ 주 정추출물 및 $60 \%$ 주정 추출물을 각각 $40 \mu \mathrm{L}$ loading 후, 도말 된 $\mathrm{LB}$ 배지에 올려 $37^{\circ} \mathrm{C}, 12 \mathrm{~h}$ 배양하여 미생물 생육 저지환의 크기 $(\mathrm{mm})$ 를 측정하였다. 이때 시험에 사용한 추출물은 각각 동결 건조하여

Table 1. The anti-microbial effects of each extracts on $P$. aeruginosa and $S$. aureus.

\begin{tabular}{llcccc}
\hline \multirow{2}{*}{ Bacteria } & & \multicolumn{3}{c}{ Inhibition zone diameter $(\mathrm{mm})$} \\
\cline { 2 - 6 } & Extracts & Dendropanax & Sea salt & Spinach & 0 \\
P. aeruginosa & Distilled water & 12 & 0 & 0 & 0 \\
& $30 \%$ ethanol & 11 & 0 & 0 & 0 \\
& $60 \%$ ethanol & 11 & 0 & 0 & 0 \\
S. aureus & Distilled water & 21 & 0 & 0 & 0 \\
& $30 \%$ ethanol & 18 & 0 & 0 & 0 \\
\hline
\end{tabular}

P. aeruginosa, Pseudomonas aeruginosa; S. aureus, Staphylococcus aureus. 
A

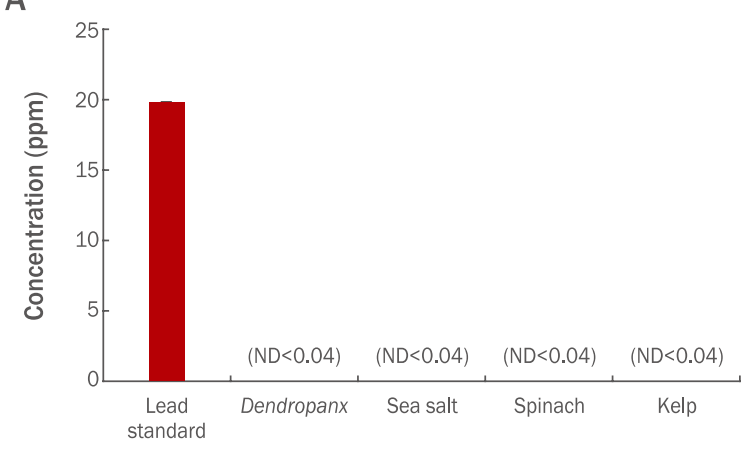

C

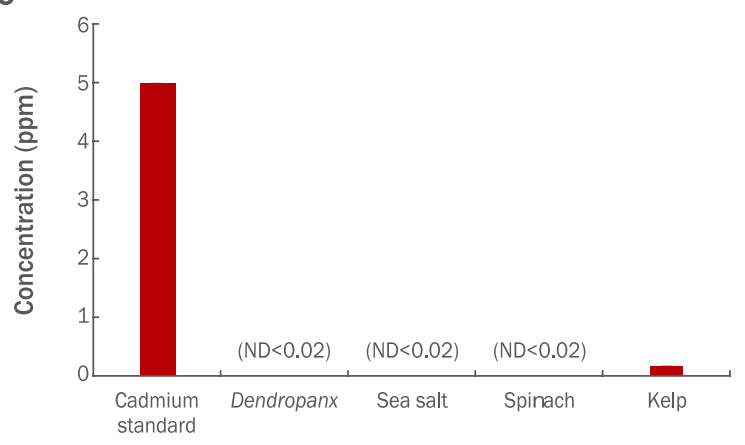

B

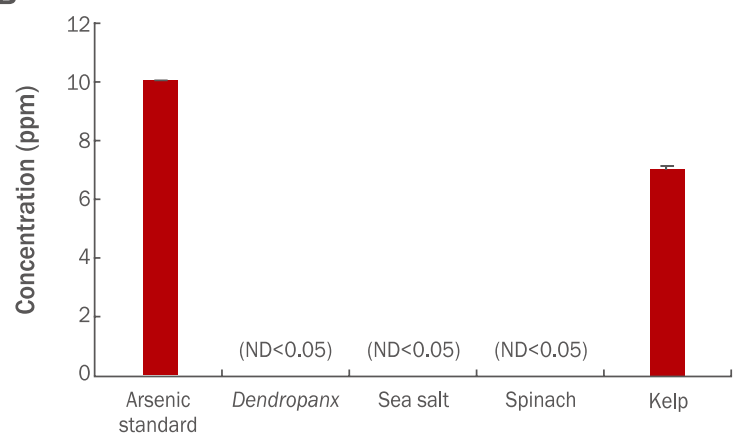

D

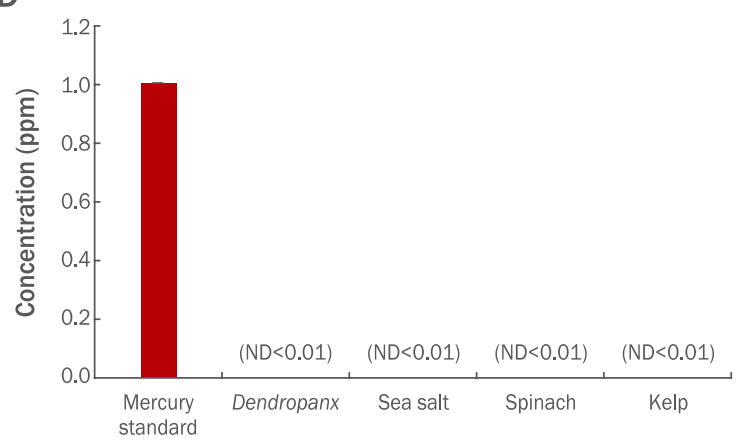

Figure 1. The safety of heavy metals in Dendropanax, sea salt, spinach, and kelp.

We confirmed the extracts' safety considering the Ministry of Food and Drug Safety's (MFDS) standards. Each bar indicates the mean \pm standard deviation of determinations $(n=3)$. We used a one-way ANOVA $(p<0.05)$ as our statistical analysis.

$100 \mathrm{mg} / \mathrm{mL}$ 농도로 녹인 것을 사용하였다.

\section{II. 세포 증식율}

세포 증식율 확인을 위한 모유두세포는 혼합배지(follicle dermal papilla cell growth medium kit)를 사용하여 incubator 에서 $37^{\circ} \mathrm{C}, 5 \% \mathrm{CO}_{2}$ 조건으로 배양하였다(Park et al., 2010; Wang et al., 2019). 사용한 혼합배지는 세포 독성 시 사용한 배지 (DMEM+FBS+P/S)와 유사한 내용물이 함유된 배지로써 보다 신 속한 실험결과 도출에 활용되었다. 모유두세포의 세포 증식율은 열수 추출물에 대하여 세포 독성이 없는 범위 내에서 농도별로 처 리하였고, 대조군으로는 동일한 양의 멸균수를 사용하였다. 모유 두세포를 96 well plate에 well당 $1 \times 10^{6}$ cells로 $100 \mu \mathrm{L}$ 를 분주 한 후 incubator에서 $37^{\circ} \mathrm{C}, 5 \% \mathrm{CO}_{2}$ 조건으로 $12 \mathrm{~h}$ 배양하였다. 그 리고 각 추출물은 농도별로 처리하고 다시 $24 \mathrm{~h}$ 배양하였다. 배양 후 MTS assay에 따라 각 well 당 MTS시료(CellTiter 96®AQueous One Solution Cell Proliferation Assay, PROMEGA, USA)를 $20 \mu \mathrm{L}$ loading하고 $4 \mathrm{~h}$ 배양 후, OD $490 \mathrm{~nm}$ 에서 흡광도를 측정하였다.

\section{III. 항염증}

항염증 확인을 위한 Raw 264.7 세포(Korea cell line bank,
KCLB; Korea)는 90\% DMEM에 10\% FBS 및 $1 \% \mathrm{P} / \mathrm{S}$ 를 첨가하 고, incubator에서 $37^{\circ} \mathrm{C}, 5 \% \mathrm{CO}_{2}$ 조건으로 배양하였다(Kim et al., 2018; Shim, 2019; Kim \& Ko, 2020). 열수 추출물, 30\% 주 정 추출물 및 $60 \%$ 주정 추출물의 항염증 반응을 확인하기 위해 Raw 264.7 세포를 96 well plate에 well당 $1 \times 10^{5}$ cells로 $100 \mu \mathrm{L}$ 를 분주 후, incubator에 $37^{\circ} \mathrm{C}, 5 \% \mathrm{CO}_{2}$ 조건으로 $12 \mathrm{~h}$ 배양하였다. Lipopolysaccharide (LPS; Sigma Aldrich, USA)는 모두 동일한 1 $\mu \mathrm{g} / \mathrm{mL}$ 를 처리한 후, 황칠은 $1,5,10 \mu \mathrm{g} / \mathrm{mL}$ 열수 추출물의 농도로 처리하고, 천일염은 $100,500,1000 \mu \mathrm{g} / \mathrm{mL}$ 열수 추출물, $30 \%$ 주 정 추출물 및 $60 \%$ 주정 추출물의 농도로 처리하였다. 시금치와 다 시마는 50,100 및 $500 \mu \mathrm{g} / \mathrm{mL}$ 열수 추출물, $30 \%$ 주정 추출물 및 $60 \%$ 주정 추출물의 농도로 각각 처리하였다. $24 \mathrm{~h}$ 배양하고, Griess reagent (Sigma Aldrich, USA)를 처리하였다. 이 후 상온, 암실에 서 $10 \mathrm{~min}$ 반응시킨 후, $\mathrm{OD} 540 \mathrm{~nm}$ 에서 흡광도를 측정하여 nitric oxide $(\mathrm{NO})$ 생성량을 확인하였다.

\section{4. 통계 분석}

통계 분석은 GraphPad 프로그램(GraphPad Software, USA)을 이용하여 평균값과 표준편차를 산출하였다. 각 군 간의 유의성은 일 원분산분석(one-way analysis of variance, one-way ANOVA)으로 
A
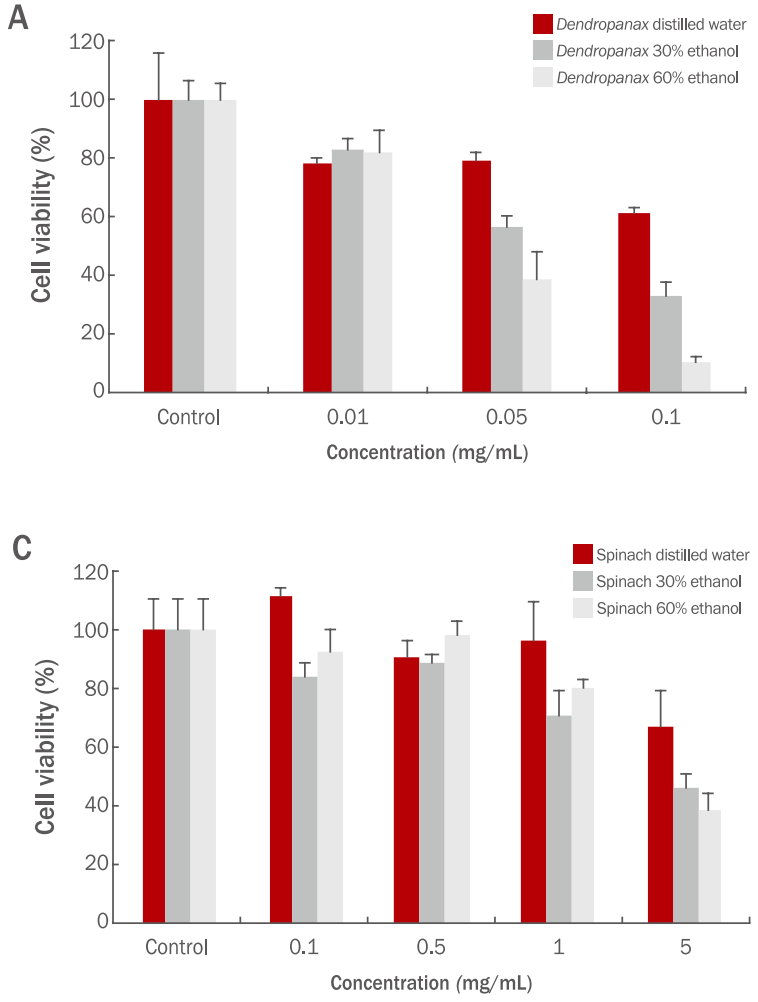

B

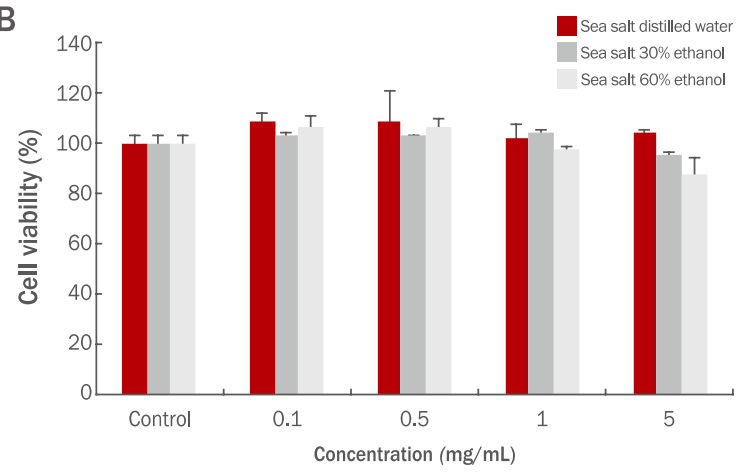

D

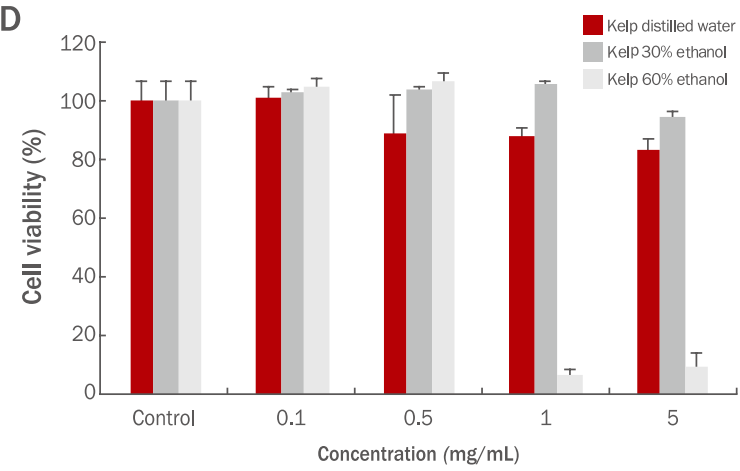

Figure 2. The cytotoxicity of distilled water, $30 \%$ ethanol, and $60 \%$ ethanol extracts at various concentrations in HFDPC cells using EZ-Cytox.

We confirmed the Dendropanax extracts' concentration to $0.1 \mathrm{mg} / \mathrm{mL}$ (A) because of the cytotoxicity at higher concentrations, whereas the concentration was established as $5 \mathrm{mg} / \mathrm{mL}$ for sea salt (B), spinach (C), and kelp (D). Each bar indicates the mean \pm standard deviation of determinations $(n=3)$. We used a one-way ANOVA $(p<0.05)$ as our statistical analysis. HFDPC, human follicle dermal papilla cell.

확인하였고, 모든 처리값의 차이는 신뢰수준 $95 \%$ ( $p<0.05)$ 로 검증 하였다.

\section{Results \& Discussion}

\section{1. 안전성 시험}

\section{I. 중금속}

각 추출물의 중금속은 식품의약품안전처에서 고시한「유통화장 품 안전관리 기준」에 따라 납은 $20 \mathrm{ppm}$ 이하, 비소는 $10 \mathrm{ppm}$ 이 하, 카드뮴은 $5 \mathrm{ppm}$ 이하 및 수은은 $1 \mathrm{ppm}$ 이하로써 안전성 기준에 적합한지 여부를 확인하였다(Figure 1). 황칠, 천일염 및 시금치 추 출물에 대하여는 납, 비소, 카드뮴 및 수은 모두 안전성 기준보다 적 거나 극미량 수준인 것으로 확인되었다(Figure 1). 다만 다시마 추 출물의 경우, 비소가 약 $7 \mathrm{ppm}$ 정도로써 확인되어 안전성 기준 10 $\mathrm{ppm}$ 보다는 낮으나 비교적 높은 수준인 것으로 분석되었다(Figure 1B).

\section{II. 세포 독성}

각 추출물에 대한 모유두세포(HFDPC)의 세포 독성 농도를 확인 하였다(Figure 2). 황칠 열수 추출물은 $0.05 \mathrm{mg} / \mathrm{mL}$ 농도까지 약 $80 \%$ 세포생존율을 나타내었고, $0.1 \mathrm{mg} / \mathrm{mL}$ 농도에서 약 $60 \%$ 세포 생존율을 나타내었다(Figure 2A). $30 \%$ 주정 추출물은 $0.01 \mathrm{mg} / \mathrm{mL}$ 농도에서 약 $80 \%$ 이상의 세포생존율을 보였으나, $0.05 \mathrm{mg} / \mathrm{mL}$ 에 서 약 $60 \%, 0.1 \mathrm{mg} / \mathrm{mL}$ 에서 약 $20 \%$ 세포생존율을 보임으로써 강 한 세포 독성이 확인되었다. 또한 $60 \%$ 주정 추출물에서도 $0.01 \mathrm{mg} /$ $\mathrm{mL}$ 농도까지 약 $80 \%$ 의 높은 세포생존율을 보였으나, $0.05 \mathrm{mg} /$ $\mathrm{mL}$ 에서 약 $40 \%, 0.1 \mathrm{mg} / \mathrm{mL}$ 에서 약 $10 \%$ 세포생존율을 보임으로 써 강한 세포 독성이 확인되었다. 이상의 결과에서 나타난 바와 같 이 $30 \%$ 및 $60 \%$ 주정 추출물 모두에서 세포생존율이 농도의존적으 로 감소하는 것은 주정 자체의 독성으로 기인한 것인지, 황칠 자체 의 독성으로 기인한 것인지, 본 연구의 결과로는 확인할 수 없으나, $0.1 \mathrm{mg} / \mathrm{mL}$ 이내의 천일염, 시금치 및 다시마의 모든 주정 추출물에 서 세포 독성이 나타나지 않았기 때문에 주정의 영향으로 판단하기 보다는 황칠 자체의 독성에 기인한 것으로 판단한다. 반면 천일염의 열수 추출물, $30 \%$ 주정 추출물 및 $60 \%$ 주정 추출물은 $5 \mathrm{mg} / \mathrm{mL}$ 농 
A
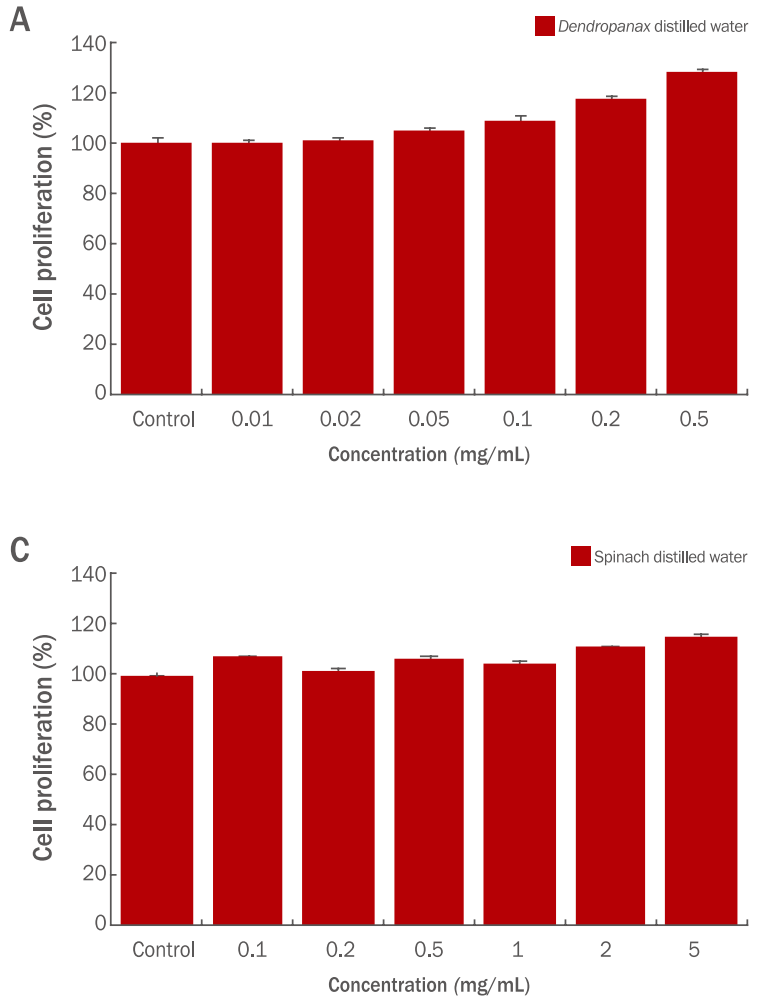

B

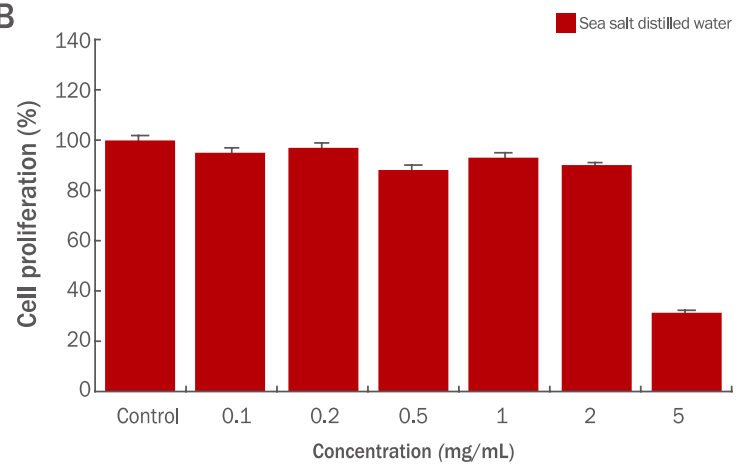

D

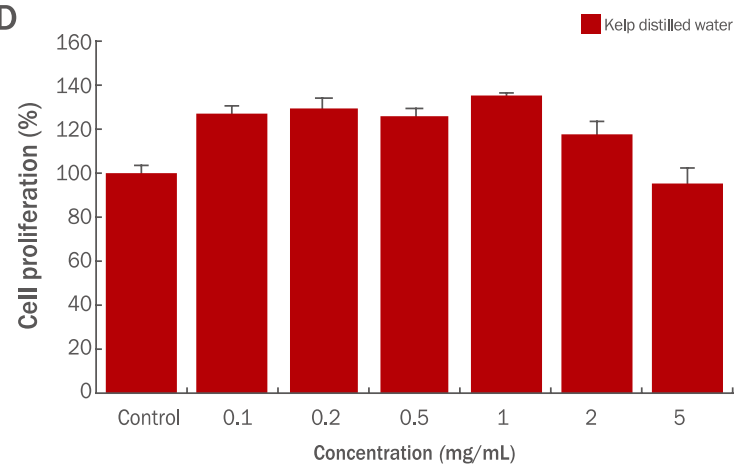

Figure 3. The cell proliferation of distilled water extracts at the various concentration in HFDPC cells.

We confirmed the Dendropanax extracts' concentration to $0.1 \mathrm{mg} / \mathrm{mL}$ (A) because of the cytotoxicity at higher concentrations, whereas the concentration was established as $5 \mathrm{mg} / \mathrm{mL}$ for sea salt (B), spinach (C), and kelp (D). Each bar indicates the mean \pm standard deviation of determinations $(n=3)$. We used a one-way ANOVA $(p<0.05)$ as our statistical analysis.

도까지도 모두 80\% 이상의 세포 안전성이 확인되었다(Figure 2B). 시금치 열수 추출물의 경우 $1 \mathrm{mg} / \mathrm{mL}$ 농도까지 약 $90 \%$ 세포생존율 을 나타내었으나, $5 \mathrm{mg} / \mathrm{mL}$ 농도에서 약 $70 \%$ 세포생존율을 보였다 (Figure 2C). $30 \%$ 주정 추출물은 $1 \mathrm{mg} / \mathrm{mL}$ 에서 약 $60 \%, 5 \mathrm{mg} / \mathrm{mL}$ 에서 약 $40 \%$ 세포생존율을 나타내었다. 또한 $60 \%$ 주정 추출물에서 도 $1 \mathrm{mg} / \mathrm{mL}$ 농도까지 약 80\%의 높은 세포생존율을 보였으나, 5 $\mathrm{mg} / \mathrm{mL}$ 에서 약 $40 \%$ 세포생존율을 나타내었다. 다시마 열수 추출물 및 $30 \%$ 주정 추출물은 $5 \mathrm{mg} / \mathrm{mL}$ 까지 $80 \%$ 이상의 세포생존율을 나 타내었으나, $60 \%$ 주정 추출물은 1-5 mg/mL 농도에서 약 $10 \%$ 세 포생존율을 보임으로써 강한 세포 독성이 확인되었다(Figure 2D). 따라서 본 세포 독성 결과를 통해 각 추출물의 사용 가능한 농도범위 를 선정하여 항염증 시험에 적용하였으며, 특히 항염증에 효과가 나 타나는 범위에 대해서는 세포 독성 농도범위를 확대하여 실험결과를 도출하였다. 따라서 세포 증식율 시험의 경우, 황칠은 열수 추출물 $0.1 \mathrm{mg} / \mathrm{mL}$ 이 아닌 $0.5 \mathrm{mg} / \mathrm{mL}$ 농도까지 확인한 반면, 천일염, 시 금치 및 다시마는 열수 추출물의 세포 독성 범위와 동일하게 $5 \mathrm{mg} /$ $\mathrm{mL}$ 농도까지 확인하였다. 또한 항염증 실험에 있어서도 황칠은 열 수 추출물 $0.1 \mathrm{mg} / \mathrm{mL}$ 이 아닌 $10 \mu \mathrm{g} / \mathrm{mL}$ 농도까지 확인하였고, 천 일염도 각 추출물에 대하여 $5 \mathrm{mg} / \mathrm{mL}$ 이 아닌 $1000 \mu \mathrm{g} / \mathrm{mL}$ 농도까
지 확인하였으며, 시금치 및 다시마 또한 각 추출물에 대하여 $5 \mathrm{mg} /$ $\mathrm{mL}$ 이 아닌 $500 \mu \mathrm{g} / \mathrm{mL}$ 농도까지 확인하였다.

\section{2. 유효성 시험}

\section{I. 항균 활성}

항균 활성 결과, 황칠의 경우 녹농균에 대하여는 열수 추출물 12 $\mathrm{mm}, 30 \%$ 주정 추출물 $11 \mathrm{~mm}$ 및 $60 \%$ 주정 추출물 $11 \mathrm{~mm}$ 크기로 써 생육 저지환이 확인되었고, 황색포도상구균에 대하여는 열수 추 출물 $21 \mathrm{~mm}, 30 \%$ 주정 추출물 $18 \mathrm{~mm}$ 및 $60 \%$ 주정 추출물 $17 \mathrm{~mm}$ 크기로써 생육 저지환이 확인되었다. 다만 천일염, 시금치 및 다시마 에서는 항균 활성이 확인되지 않았다(Table 1). 따라서 황칠은 천일 염, 시금치 및 다시마에는 없는 항균력이 있는 소재로서 제품개발 가 능성을 확인할 수 있었다.

\section{II. 세포 증식율}

모유두세포는 모낭의 기저부에 존재하는 세포로써 모발의 성장 과 주기 조절을 담당하며, 이 세포의 증식이 촉진되면 모발이 건강 해지고 모발 성장이 촉진되어 탈모를 예방할 수 있다(Brenner \& Bergfeld, 2003; Rastegar et al., 2015; Choi et al., 2017). 본 시 
A

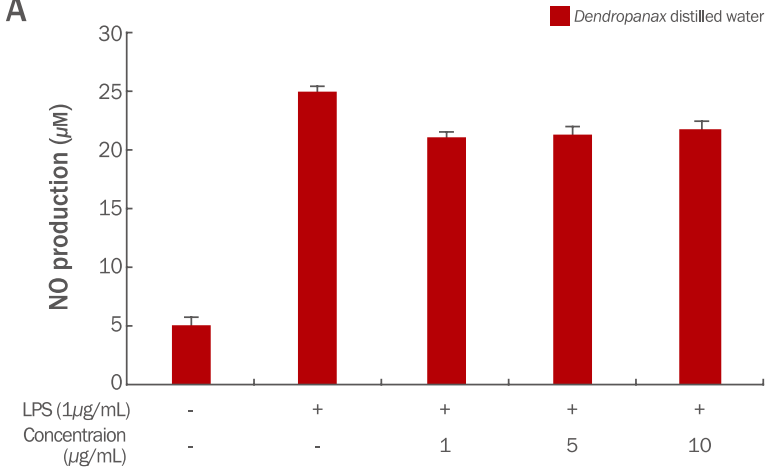

C

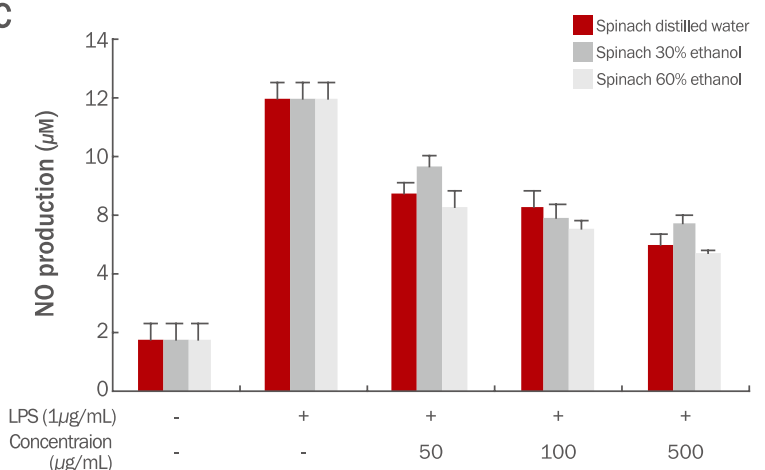

B

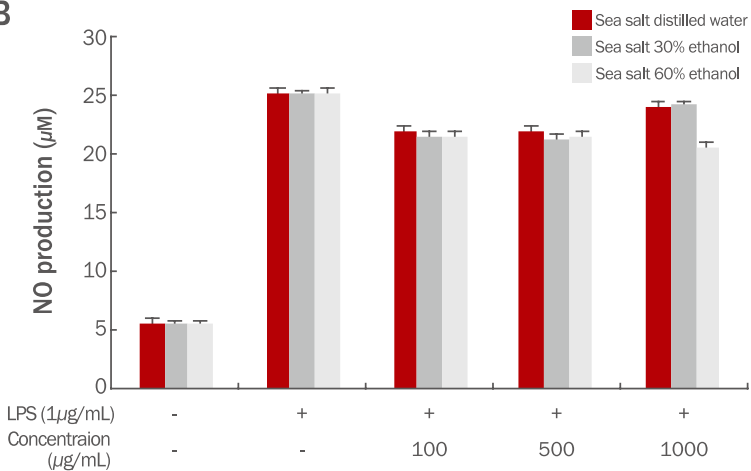

D

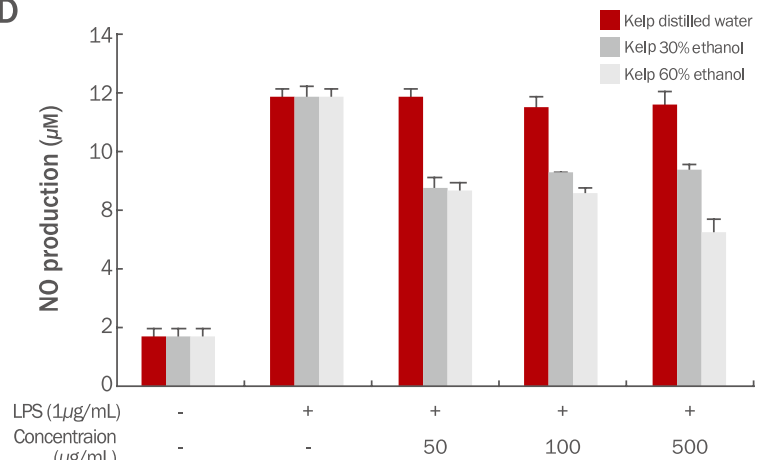

Figure 4. The extracts' anti-inflammation effects on NO production in LPS activated Raw 264.7 cells.

We treated the cells with distilled water, $30 \%$ and $60 \%$ ethanol extracts of sea salt, spinach, and kelp. We observed the Dendropanax extract's effect only in distilled water up to $10 \mu \mathrm{g} / \mathrm{mL}$ (A), for the sea salt extract (B) up to $1000 \mu \mathrm{g} / \mathrm{mL}$, and for both spinach (C) and kelp (D) extracts at $500 \mu \mathrm{g} / \mathrm{mL}$. Each bar indicates the mean \pm standard deviation of determinations $(n=3)$. We used a one-way ANOVA $(p<0.05)$ as our statistical analysis. No, nitric oxide; LPS, lipopolysaccharide.

험에서는 모유두세포에 독성이 없는 열수 추출물에 한하여 농도별 로 처리한 후, 세포 증식율을 확인하였다(Figure 3). 황칠의 경우 $0.01-0.5 \mathrm{mg} / \mathrm{mL}$ 범위에서 농도가 증가할수록 세포 증식율도 증가 하였다(Figure $3 \mathrm{~A}$ ). 천일염은 $0.1-2 \mathrm{mg} / \mathrm{mL}$ 범위에서 세포 증식율 의 변화가 없었으나, $5 \mathrm{mg} / \mathrm{mL}$ 에서는 오히려 세포 증식율이 약 $30 \%$ 까지 크게 감소하였다(Figure 3B). 그리고 시금치는 $0.1-5 \mathrm{mg} / \mathrm{mL}$ 범위에서 농도가 증가할수록 세포 증식율도 증가하였다(Figure 3C), 또한 다시마의 경우 $0.1-2 \mathrm{mg} / \mathrm{mL}$ 범위에서 세포 증식율이 증가한 반면, $5 \mathrm{mg} / \mathrm{mL}$ 범위에서는 다소 감소한 것으로 나타났다(Figure $3 \mathrm{D})$. 결과적으로 천일염을 제외한 황칠, 시금치 및 다시마 등의 열 수 추출물에서 세포 증식율이 증가한 것으로 확인되었다. 이는 세포 증식율 시험에서 열수 추출물로만 실험을 수행한 이유와 관계가 있 으며, 일반적으로 천연물을 화장품 원료로 사용할 때에는 주정이 아 닌 물 추출물이 가격적인 면과 안전성 면에서 보다 활용 가치가 높 기 때문에 열수 추출물에서 효과가 확인된 것을 토대로 본 연구에서 는 $30 \%$ 주정 추출물 및 $60 \%$ 주정추출물로는 추가 실험을 수행하지 않았다. 따라서 앞으로의 연구에서는 주정 추출물의 세포 증식율도
추가로 확인함으로써 화장품 원료화 가능성을 열수 추출물에서 주정 추출물까지 확대 적용하는 것도 고려해야 할 것이다. 또한 황칠 열 수 추출물의 경우, $0.1 \mathrm{mg} / \mathrm{mL}$ 에서 약 $60 \%$ 까지 세포생존율이 감소 한 것과는 달리 세포 증식율이 $0.01-0.5 \mathrm{mg} / \mathrm{mL}$ 범위에서 증가한 것은 일반적인 경우는 아니지만, 천연물의 경우 항시 발생할 수 있는 사례이기 때문에 향후에는 이러한 결과에 대하여도 추가적인 실험이 필요할 것으로 사료된다.

\section{III. 항염증}

Raw 264.7 세포에 LPS를 처리한 후 세포 독성이 없는 범위 내에 서 각 추출물의 NO 생성량을 확인하였다(Figure 4). 황칠 열수 추출 물의 경우 1-10 $\mu \mathrm{g} / \mathrm{mL}$ 농도에서 $\mathrm{NO}$ 생성량이 감소함에 따라 항염 증 효과를 확인할 수 있었고(Figure $4 \mathrm{~A}$ ), 특히 황칠은 $30 \%$ 주정 추 출물과 $60 \%$ 주정 추출물을 제외한 열수 추출물로만 결과를 도출하 였는데 그 이유는 세포 독성 결과에서 보는 바와 같이 $0.01 \mathrm{mg} / \mathrm{mL}$ $(10 \mu \mathrm{g} / \mathrm{mL})$ 이내의 농도범위 까지는 열수 추출물, $30 \%$ 주정 추출 물 및 $60 \%$ 주정 추출물 모두에서 $80 \%$ 이상의 세포생존율을 나타낸 
반면, $0.05-0.1 \mathrm{mg} / \mathrm{mL}$ 에서는 $30 \%$ 주정 추출물 및 $60 \%$ 주정 추출 물의 약 $50 \%$ 이내의 세포생존율을 나타냈기 때문에 열수 추출물의 $0.01 \mathrm{mg} / \mathrm{mL}$ 이내의 농도범위에서 $\mathrm{NO}$ 생성량을 확인하게 되었다 (Figure 2A). 천일염의 열수 추출물, $30 \%$ 주정 추출물 및 $60 \%$ 주정 추출물에서도 100-1000 $\mu \mathrm{g} / \mathrm{mL}$ 범위에서 NO생성량이 모두 감소 하였다(Figure 4B). 특히 시금치의 경우에는 열수 추출물, $30 \%$ 주정 추출물 및 $60 \%$ 주정 추출물은 $50-500 \mu \mathrm{g} / \mathrm{mL}$ 범위에서 농도 의존 적으로 $\mathrm{NO}$ 생성량이 감소하는 것으로 확인되었다(Figure 4C). 또한 다시마의 경우 열수 추출물은 NO 생성량에 변화가 없었으나, $30 \%$ 주정 추출물과 $60 \%$ 주정 추출물은 $50-500 \mu \mathrm{g} / \mathrm{mL}$ 범위에서 각각 $\mathrm{NO}$ 생성량이 감소하였고, 특히 $60 \%$ 주정 추출물에서도 농도 의존 적인 항염증 결과를 확인할 수 있었다(Figure 4D). 따라서, 각 추출 물은 제한된 범위 내에서 $\mathrm{NO}$ 생성량이 감소하였기 때문에 항염증 효과를 통한 화장품 소재화가 가능할 것으로 사료된다.

\section{Conclusion}

본 연구는 황칠 및 천일염 등을 이용한 탈모 증상 완화에 도움을 줄 수 있는 기능성 화장품 소재개발을 위한 기초 연구로써 국내산 황 칠과 천일염 이외에도 시금치 및 다시마에 대한 중금속 및 세포 독성 시험을 통해 추출물의 안전성을 확인하고, 항균 활성, 세포 증식율 및 항염증 시험을 통한 유효성을 확인하고자 수행되었다.

그 결과 중금속은 황칠, 천일염, 시금치 및 다시마 추출물에 대해 납, 비소, 카드뮴 및 수은이 식품의약품안전처에서 제시한 안전성 기 준치보다 낮거나 극미량 수준인 것으로 확인되었다. 세포 독성은 열 수 추출물의 경우 황칠 $0.05 \mathrm{mg} / \mathrm{mL}$, 천일염 $5 \mathrm{mg} / \mathrm{mL}$, 시금치 1 $\mathrm{mg} / \mathrm{mL}$ 및 다시마 $1 \mathrm{mg} / \mathrm{mL}$ 농도 이내에서 안전한 것으로 확인되 었고, $30 \%$ 주정 추출물은 황칠 $0.01 \mathrm{mg} / \mathrm{mL}$, 천일염 $5 \mathrm{mg} / \mathrm{mL}$, 시 금치 $0.5 \mathrm{mg} / \mathrm{mL}$ 및 다시마 $5 \mathrm{mg} / \mathrm{mL}$ 농도 이내에서 안전한 것으 로 확인되었으며, $60 \%$ 주정 추출물은 황칠 $0.01 \mathrm{mg} / \mathrm{mL}$, 천일염 5 $\mathrm{mg} / \mathrm{mL}$, 시금치 $0.5 \mathrm{mg} / \mathrm{mL}$ 및 다시마 $0.5 \mathrm{mg} / \mathrm{mL}$ 농도 이내에서 안전한 것으로 확인되었다. 또한 항균 활성은 천일염, 시금치 및 다 시마를 제외한 황칠 추출물에서만 효과가 나타났고, 그 중 황칠 열 수 추출물에서 녹농균 $12 \mathrm{~mm}$, 황색포도상구균 $21 \mathrm{~mm}$ 로써 가장 높 은 효과를 확인하였다. 세포 증식율에서는 열수 추출물에 대하여 황 칠 $0.5 \mathrm{mg} / \mathrm{mL}$, 시금치 $5 \mathrm{mg} / \mathrm{mL}$ 및 다시마 $2 \mathrm{mg} / \mathrm{mL}$ 까지 증가한 반면, 천일염은 $2 \mathrm{mg} / \mathrm{mL}$ 까지 세포 증식율에 변화가 없는 것으로 확 인되었다. 항염증에 대하여는 다시마 열수 추출물을 제외한 모든 추 출물에서 NO 생성량이 감소함에 따라 항염증 효과를 확인할 수 있 었다. 특히 시금치 열수, $30 \%$ 주정 및 $60 \%$ 주정 추출물과 다시마의 $60 \%$ 주정 추출물의 경우 $50-500 \mu \mathrm{g} / \mathrm{mL}$ 범위에서 농도 의존적으로 $\mathrm{NO}$ 생성량이 감소하는 경향을 나타내었다

이상의 결과를 토대로 전남 특산자원인 황칠과 천일염 등의 열수
추출물은 전반적으로 주정 추출물에 비하여 높은 안전성과 최적화된 농도 범위내에서 탈모 증상 완화에 도움을 줄 수 유효성이 확인되었 기 때문에 추가적인 원료 표준화 연구와 유효 성분을 입증함으로써 향후, 두발용 샴푸 등의 다양한 제품으로 활용될 수 있을 것으로 기 대되어 진다.

\section{Acknowledgements}

본 연구는 2017년 (재)전남테크노파크에서 주관하는 지역수요 맞춤형 연구개발사업의 일환으로 수행한 연구 결과물임을 밝힙니 다.

\section{Author's contribution}

YHC conducted cytotoxicity, cell proliferation and anti-inflammatory experiments, analyzed the data, and compiled all tables and figures. YJC prepared research and manuscripts on test methods and resource information, and BLK extracted, concentrated and freeze-dried resources, and supported heavy metal experiments. MHH conducted antimicrobial and heavy metal experiments. HSL supervised the project, and YGJ performed all aspects of experiment design, resource research and data analysis. Finally, YGJ wrote the manuscript with the help of HSL.

\section{Author details}

Yun-Hee Choi (Researcher), Center of Natural Resources Research, Jeonnam Bioindustry Foundation, 288 Woodlandgil, Anyang-myeon, Jangheung-gun, Jeollanam-do 59338, Korea; Yeon-Je Cho (Researcher), Center of Natural Resources Research, Jeonnam Bioindustry Foundation, 288 Woodland-gil, Anyang-myeon, Jangheung-gun, Jeollanam-do 59338, Korea; Byung-Loc Kim (Researcher), Center of Natural Resources Research, Jeonnam Bioindustry Foundation, Woodland-gil, Anyang-myeon, Jangheung-gun, Jeollanam-do 59338, Korea; Min-Hee Han (Researcher), Center of Natural Resources Research, Jeonnam Bioindustry Foundation, 288 Woodland-gil, Anyang-myeon, Jangheung-gun, Jeollanam-do 59338, Korea; Hak-Sung Lee (Director), Center of Natural Resources Research, Jeonnam Bioindustry Foundation, 288 Woodland-gil, Anyang-myeon, Jangheung-gun, Jeollanam-do 59338, Korea; Yong-Gi Jeong (Manager), Center of Natural Resources Research, Jeonnam Bioindustry Foundation, 288 Woodland-gil, Anyang-myeon, Jangheung-gun, Jeollanam-do 59338, Korea. 


\section{References}

Brenner FM, Bergfeld WF. Hair loss: diagnosis and management. Cleveland Clinic Journal of Medicine, 70: 705-712, 2003.

Choi JH, Lee M, Kim HJ, Kwon Jl. Effects of black soybean and fermented black soybean extracts on proliferation of human follicle dermal papilla cells. Journal of the Korean Society of Food Science and Nutrition. 46: 671-680, 2017.

Hu SJ, Kim M, Park SK, Lee JO. Heavy metal contents in ginseng and ginseng products. Korean Journal of Food Science and Technology, 37: 329-333, 2005.

Jung GB, Lee JS, Kim WI, Kim JH. Wet deposition of heavy metals in Suwon area. Korean Journal of Environmental Agriculture, 26: 116-123, 2007.

Jung GB, Kim MK, Lee JS, Kim WI, Kim GY, Ko BG, Kang KK, Kwon SI. Wet deposition of heavy metals during farming season in Taean, Korea. Korean Journal of Environmental Agriculture, 30: 153-159, 2011.

Jung KI, Kim BK, Kang JH, Oh GH, Kim IK, Kim M. Antioxidant and anti-inflammatory activities of water and the fermentation liquid of sea tangle (Saccharina japonica). Journal of Life Science, 29: 596-606, 2019.

Kim J, Jo A, Lee J. Analysis of the patent trends for natural components related to hair loss. Asia-pacific Journal of Multimedia Services Convergent with Art, Humanities, and Sociology, 9: 375-387, 2019a.

Kim BL, Choi YH, Lee HS, Jeong YG. Comparative analysis of heavy metals and useful components of marine resources with potential healing properties. Asian Journal of Beauty and Cosmetology, 17: 455-466, 2019b.

Kim D, Park S. Pharmacological therapeutics in androgenetic alopecia. Journal of the Korean Medical Association, 63: 277-285, 2020.

Kim GW, Choi YH, Kim BL, Kim YU, Seong RS, Han MH, Kim GA, Choi MJ, Jeong YG. Determination of anti-oxidative and whitening effects of complex extracts obtained from Sprout Panax ginseng C.A. Meyer and Cassia nomame (Sieb.) Honda on skin. Asian Journal of Beauty and Cosmetology, 16: 309-320, 2018.

Kim HL, Lee IS, Kim IC. Evaluation of mineral, heavy metal and phthalate contents in mudflat solar salt and foreign salt. Korean Journal of Food Preservation, 21: 520-528, 2014.

Kim HS, Ko KS. Antioxidant and anti-inflammatory effects of ginseng berry ethanol extracts as a cosmetic ingredient. Asian Journal of Beauty and Cosmetology, 18: 389-397, 2020.

Kim KH, Kim JH, Song HS. The effect of salt in medicine for salt pharmacopuncture. Journal of Acupuncture Research, 32: 131-145, 2015.

Lee SY, Choi EJ, Bae DH, Lee DW, Kim S. Effects of 1-tetradecanol and $\beta$-sitosterol isolated from Dendropanax morbifera Lev. on skin whitening, moisturizing and preventing hair loss. Journal of the Society of Cosmetic Scientists of Korea, 41: 73-83, 2015a.

Lee SY, Jang MS, Kim GH. Antioxidant activities and quality characteristics of organic and conventional Spinach (Spinacia oleracea). Journal of the Korean Society of Food Culture, 30: 813-817, 2015b.

Mostafa AA, Al-Askar AA, Almaary KS, Dawoud TM, Sholkamy EN, Bakri MM. Antimicrobial activity of some plant extracts against bacterial strains causing food poisoning diseases. Saudi Journal of Biological Sciences, 25: 361366, 2018.

Park HY, Kim SN, Kang BH, Lee JH. Experimental studies of glycine maxMerr. (black bean), Triticum aestivum $\mathrm{L}$. (wheat) and Oryza sativaL. (rice bran) extracts on the effects of hair growth activity and physical properties. Korea Journal of Oriental Medicine, 16: 167-173, 2010.

Pinnell SR, Murad S. Effects of minoxidil on cultured human skin fibroblasts. Dermatologica, 175: 12-18, 1987.

Rastegar H, Ashtiani HA, Aghaei M, Barikbin B, Ehsani A. Herbal extracts induce dermal papilla cell proliferation of human hair follicles. Annals of Dermatology, 27: 667675, 2015.

Rossi A, Cantisani C, Melis L, Iorio A, Scali E, Calvieri S. Minoxidil use in dermatology, side effects and recent patents. Recent Patents on Inflammation \& Allergy Drug Discovery, 6: 130-136, 2012.

Shim JH. Anti-inflammatory effect of zeaxanthin in RAW 264.7 Cells. Asian Journal of Beauty and Cosmetology, 17: 431-439, 2019.

Wang CC, Wang LK, Chen M, Kuo CY, Tsai FM, Wang CH. Triterpenes in the ethanol extract of poria cocos induce dermal papilla cell proliferation. International Journal of Pharmacology, 16: 1-9, 2019. 


\section{국문초록}

\section{황칠과 천일염 등을 이용한 탈모증상 완화 화장품 소재개발}

최윤희, 조연제, 김병록, 한민희, 이학성, 정용기

(재)전남바이오산업진흥원 천연자원연구센터, 전라남도 장흥군, 한국

목적: 본 연구는 전남 특산자원인 황칠, 천일염, 시금치 및 다시마 등으로부터 탈모증상 완화에 도움을 줄 수 있는 기능성 화장품 개 발을 위해 소재의 안전성 및 유효성을 입증하고자 수행되었다. 방법: 안전성 시험은 황칠과 천일염 등으로부터 중금속 및 세포 독성 에 대하여 확인하였고, 유효성은 항균 활성, 세포 증식율 및 항염증에 대하여 수행하였다. 결과: 중금속은 황칠, 천일염, 시금치 및 다시마 추출물에 대해 식품의약품안전처에서 제시한 안전성 기준치보다 낮거나 극미량 수준인 것으로 확인되었다. 세포 독성은 각 추출물에 대하여 황칠 $0.01 \mathrm{mg} / \mathrm{mL}$, 천일염 $5 \mathrm{mg} / \mathrm{mL}$, 시금치 $0.5 \mathrm{mg} / \mathrm{mL}$ 및 다시마 $0.5 \mathrm{mg} / \mathrm{mL}$ 농도 이내에서 안전한 것으로 확 인되었다. 항균 활성은 황칠 추출물에서만 확인되었고, 특히 열수 추출물에서 가장 높은 효과가 있었다. 세포 증식율은 열수 추출물 에 대하여 황칠 $0.5 \mathrm{mg} / \mathrm{mL}$, 시금치 $5 \mathrm{mg} / \mathrm{mL}$ 및 다시마 $2 \mathrm{mg} / \mathrm{mL}$ 까지 증가하였다. 항염증은 다시마 열수 추출물을 제외한 모든 추출물에서 $\mathrm{NO}$ 생성량이 감소함에 따라 항염증 효과를 확인할 수 있었다. 특히 시금치 열수, $30 \%$ 주정 및 $60 \%$ 주정 추출물과 다시 마의 $60 \%$ 주정 추출물의 경우 50-500 $\mathrm{gg} / \mathrm{mL}$ 범위에서 농도 의존적으로 NO 생성량이 감소하는 경향을 나타내었다. 결론: 본 연구 에서 황칠, 천일염, 시금치 및 다시마는 화장품 소재로써 안전하고, 효과적인 것으로 확인되었다. 따라서, 추가적인 연구를 수행하 여 황칠, 천일염, 시금치 및 다시마를 포함한 최적의 표준화를 통해 탈모 증상 완화에 도움을 주는 기능성 화장품으로서 활용되어질 것으로 기대된다.

핵심어: 황칠, 천일염, 안전성, 기능성 화장품, 탈모 증상

본 연구는 2017년 (재)전남테크노파크에서 주관하는 지역수요맞춤형 연구개발사업의 일환으로 수행한 연구 결과물임을 밝힙니다.

\section{참고문헌}

김건우, 최윤희, 김병록, 김영욱, 성락선, 한민희, 김경애, 최민주, 정용기. 새싹인삼과 차풀 복합추출물의 피부 항산화 및 미백효과. 아시안뷰티화장품학술지, 18: 309-320, 2018.

김기현, 김지화, 송호섭. 염약침을 위한 소금의 의학적 효용. 대한침구의학회지, $32: 131-145,2015$.

김도영, 박수진. 안드로겐탈모증의 약물치료. 대한의사협회지, 63: 277-285, 2020.

김병록, 최윤희, 이학성, 정용기. 화장품용 해양치유자원의 안전성 및 품질 비교분석. 아시안뷰티화장품학술지, $17: 455-$ 466, 2019b.

김정원, 조아현, 이정현. 탈모 관련 천연물의 특허 동향 분석. 예술인문사회융합멀티미디어논문지, 9: 375-387, 2019a. 김학렬, 이인선, 김인철. 국내산 갯벌천일염과 외국산 소금의 미네랄, 중금속 및 phthalate 함량 평가. 한국식품저장유통 학회지, 21: $520-528,2014$.

김현숙, 고경숙. 인삼열매 에탄올 추출물의 화장품 소재로서 항산화, 항염 효과. 아시안뷰티화장품학술지, 18: 389-397, 2020.

박혜윤, 김수나, 강병하, 이존환. 검은콩, 밀, 겨 추출물이 모발의 성장과 물리 특성에 미치는 효과. 한국한의학연구원논문

집, 16: 167-173, 2010.

심중현. 제아잔틴에 의한 AW264.7 세포에서의 항염효과. 아시안뷰티화장품학술지, 17: 431-439, 2019.

이미선, 정지선, 박도영. 천일염과 청대를 활용한 두피스케일링 효능에 관한 연구. 아시안뷰티화장품학술지, 12: 119$125,2014$. 
이선영, 최은진, 배동혁, 이동욱, 김선오. 미백, 보습 및 탈모방지에 대한 황칠나무(Dendropanax modifera Lev.)에서 분 리한 1-tetradecanol, $\beta$-sitosterol의 효과. 대한화장품학회지, 41: 73-83, 2015a.

이신영, 장민선, 김건희. 유기농 및 일반재배 시금치의 이화학적 특성 및 항산화 활성. 한국식생활문화학회지, $30: 813-$ 817, 2015b.

정경임, 김보경, 강정현, 오근혜, 김인경, 김미향. 다시마 물 추출액과 발효액의 항산화 및 항염증 활성. 생명과학회지, 29: 596-606, 2019.

정구복, 이종식, 김원일, 김진호, 윤순강. 수원지역 빗물의 중금속 함량 평가. 한국환경농학회지, $26: 116-123,2007$.

정구복, 김민경, 이종식, 김원일, 김건엽, 고병구, 강기경, 권순익. 태안지역 강우의 중금속 함량 평가. 한국환경농학회지, 30: 153-159, 2011.

최지혜, 이명숙, 김현정, 권정일, 이윤경. 검은콩과 발효검은콩 추출물이 인간 모유두 세포 성장에 미치는 효과. 한국식품 영양과학회지, 46: 671-680, 2017.

허수정, 김미혜, 박성국, 이종욱. 인삼 및 인삼제품류의 중금속 함량. 한국식품과학회지, 37: 329-333. 2005. 


\section{中文摘要}

\section{Dendropanax，海盐和其他提取物的功能性美容作用可缓解脱发症状}

崔允姬，趙娟悌，金炳鹿，韓憵熙，李學成，鄭容琦”

(财)全南生物产业振兴院天然资源研究中心，全罗南道长兴郡，韩国

目的：本文评估了全南地区的独特资源（如Dendropanax，海盐，菠荣和海带）的安全性和有效性，以开发可 减轻脱发的功能性化妆品。方法: 我们使用这些资源进行了安全性测试, 测试了重金属和细胞毒性, 并评估了它 们作为抗菌，细胞增殖和抗炎产品的有效性。结果：结果显示，提取物（如Dendropanax，海盐等）的重金属 浓度低于食品和药物安全部安全标准或低于痕量水平。在每种提取物中, Dendropanax、海盐、菠荣和海带的 浓度分别为 $0.01,5,0.5,0.5 \mathrm{mg} / \mathrm{mL}$ 时, 细胞毒性是安全的。只有Dendropanax提取物具有抗菌作用, 而热 水提取物其效果最高。Dendropanax，菠荣和海带等热水提取物的细胞增殖分别提高到 $0.5 ， 5$ 和 $2 \mathrm{mg} / \mathrm{mL}$ 。除 海带的热水提取物外, 所有提取物中的NO生成量均减少而确认其抗炎作用。特别是在菠荣热水, 菠荣30\%乙醇 以及菠荣 $60 \%$ 乙醇提取物和海藻 $60 \%$ 乙醇提取物在 $50-500 \mu \mathrm{g} / \mathrm{mL}$ 的浓度范围范围内, NO产生的根据浓度依赖 性降低。结论: 我们发现Dentropanax、海盐、菠荣和海带是安全有效的美容材料, 可通过最佳标准化缓解脱发 症状。我们建议进一步研究以评估这些化妆品的功能效果。

关键词: Dendropanax, 海盐, 安全性, 功能性化妆品, 脱发症状 
